\title{
الآثار النفسية لالتحاق الطالبات المتزوجات بالدراسة في امارة العين (ابوظبى ) على حياة أسرهن من وجهه نظرهن د / محمود نخيلى عبد الرازق احمد
} جامعة عين شمس كلية التربية النوعية

الملخص: باللغه العربية:

تهدف الدراسة الحالية إلى التعرف على الاثار النفسية لالتحاق الطالبات المتزوجات بالدراسة

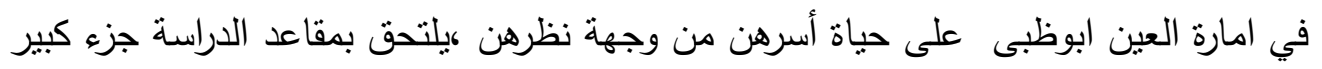

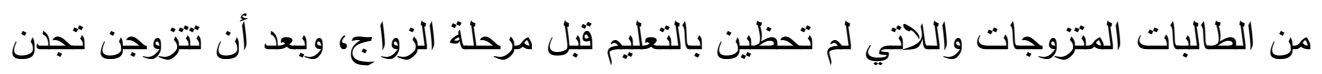

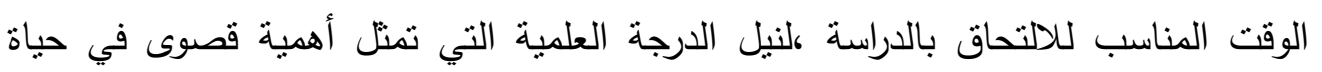
الطالبة المتزوجة، إذ في هذه المرحلة تجد الطالبة المتزوجة نفسها ومكانتها الإجنماعية

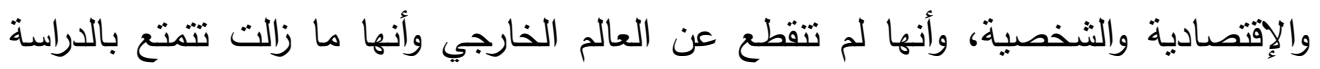

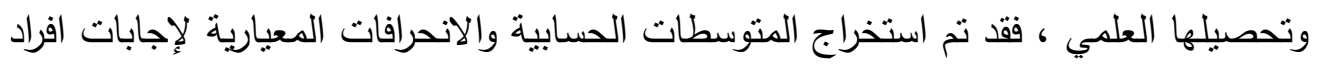

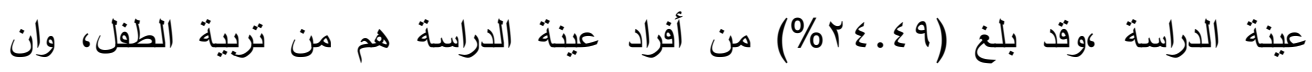

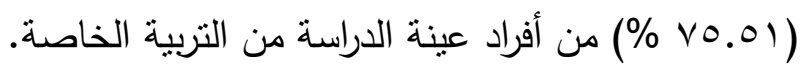


المقدمةة:

تعثبر الحياة الجامعية من أصعب مراحل الدراسة التي يمر بها طلاب الجامعات على

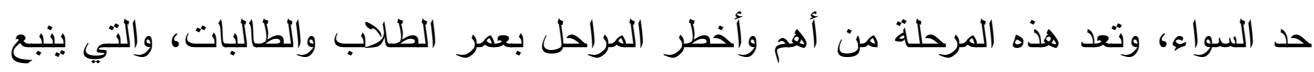
منها الوعي النقافي والمجتمعي، وتعتبر نقلة نوعية بحياة الطلاب والطالبات، فمن خلالها تتكون شخصية الطالب وتصبح عنده مجموعة من القيم والاتجاهات التي تتبع من أسلوب ونئي

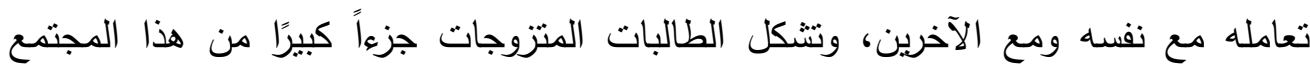
الطلابي، إذ يلتحق بمقاعد الدراسة جزء كبير من الطالبات المتزوجات واللاتي لم تحظين

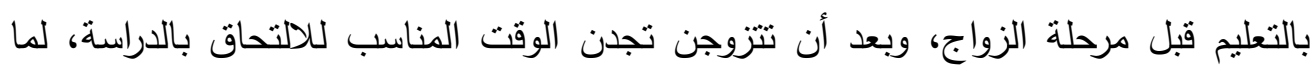

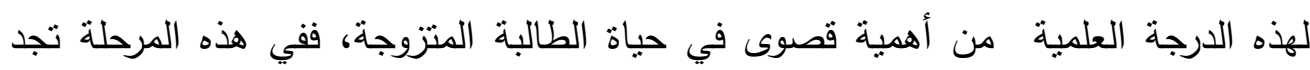

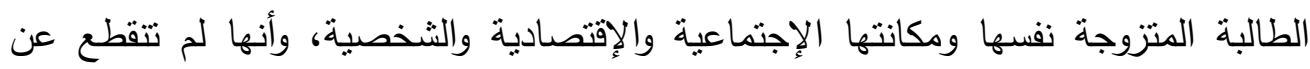

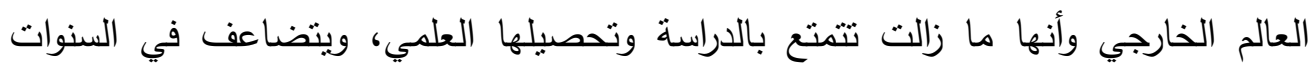

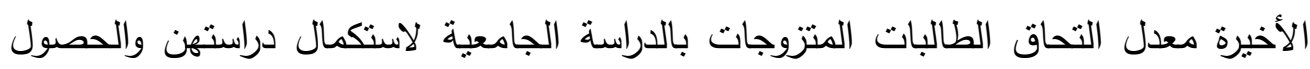
على مؤهل علمي تستطيع من خلاله أن تقوم بالعمل ومساعدة زوجها في تحمل جزء كبير

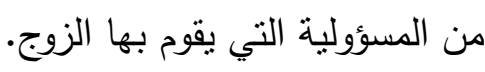
والضغوط النفسية أصبحت السمة السائدة فى هذا العصر وسنجد أن معظم الناس

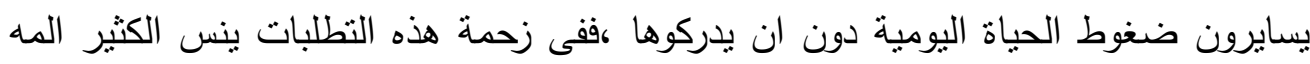
وتعبه واحباطاته باحثا عن التوافق أو التكيف مع هذه الضغوط وهذا ما بسمى بالتكيف الناجح، وحتى اسعد البشر واكثرهم توافقا مع أعماله ومع أسرته اوحتى ميسورى العئه الحال

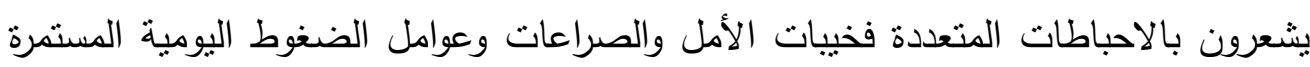
ومتطلباتتا نحو الأفضل تعرضنا إلى الإحباط، وهذه هي سنة الحياة لذلك سنجد أن الفرد العامل وعلى المستوى العام هو أكثر عرضة للضغوط النفسية فى الحياة اليومية والعادية سواء

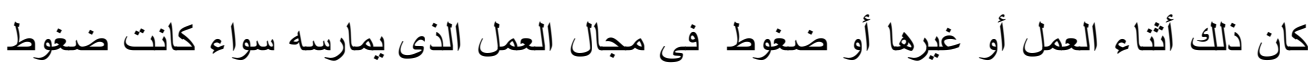

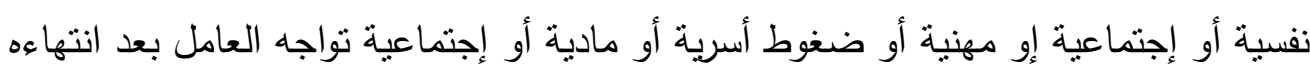

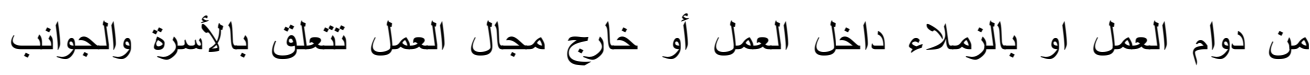

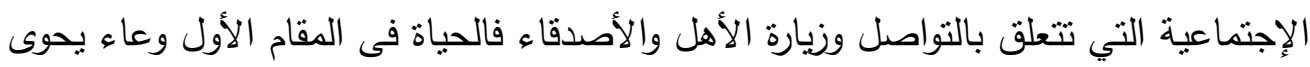

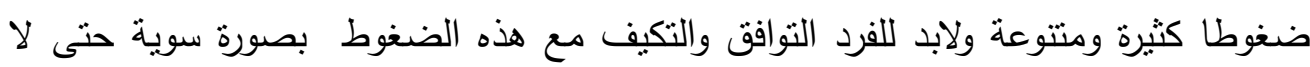
تؤثز فى نوافقه وصحته النفسية وسنجد الضغوط التي تقع على عاتق العامل كثيرة ومتتوعة 
ولكن لابد للعامل من التكيف والتوافق مع هذه الضغوط بصورة سليمة حتى لا تؤثر على

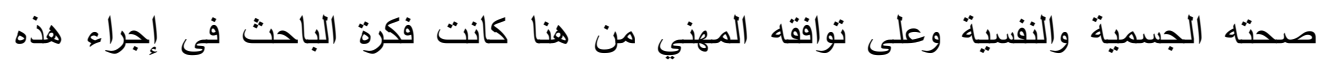

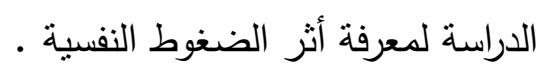
وتعتبر الآثار النفسية مشكلة تسيطر على الجميع وليس فقط على فئه المتزوجات

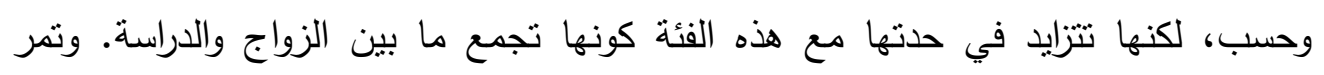

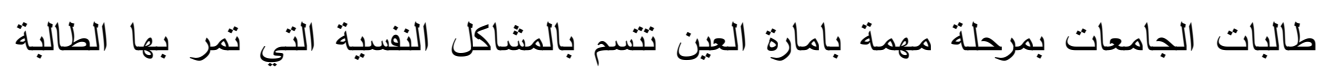

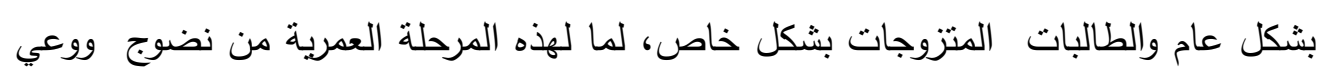
فكري ينتكل عندهن،ويعبر عن هذه المرحلة إريكسون بأنها المرحلة التي يحدث فيهاه الزئه الزواج،

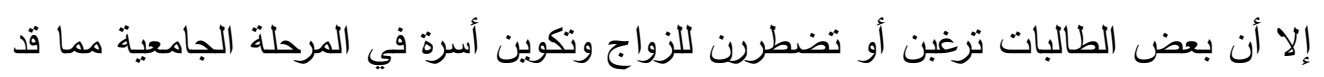

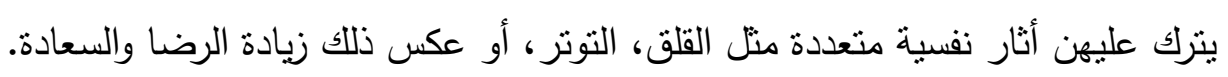

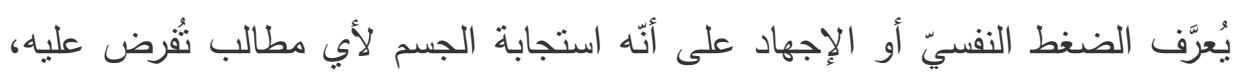
وقد تكون هذه المطالب متعلقة بالوظيفة، أو الوضع المالي، أو العلاقات، أو الجوع، أو لأو الهُ المرض، وما شابه، ويُعتبر الضغط النفسي إحدى التجارب التي تُمكّن الإنسان من التعامل

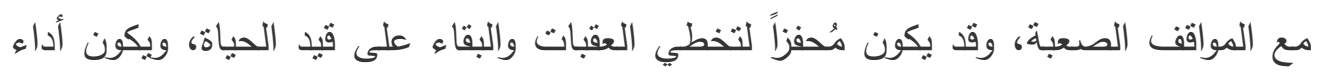

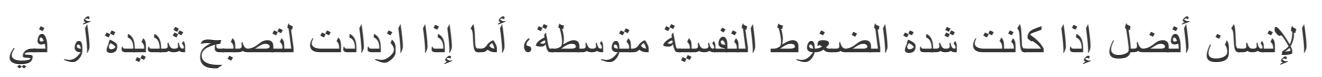
حال تعرَّ الإنسان للعديد من الضغوط النفسية في الوقت ذاته فإنّ ذلك يؤثر في أدائه التهان

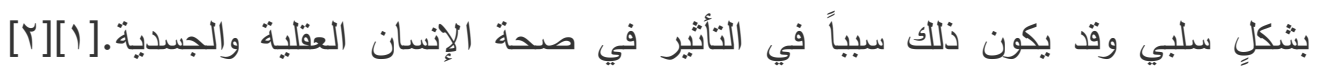

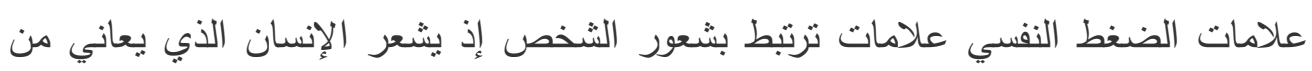

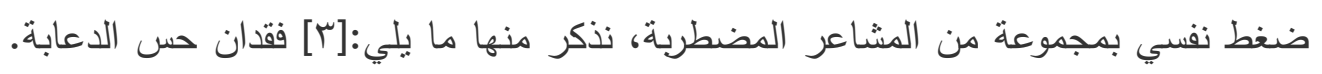

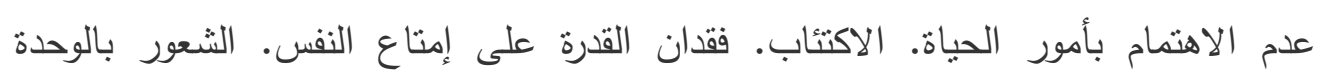
والإهمال. نفاد الصبر ، أو الاضطراب، أو العدوانية. الثعور بالقلق، أو الخوف، أو العصبية. التصنية.

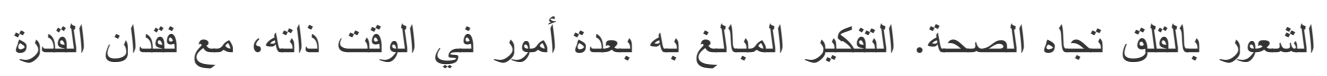

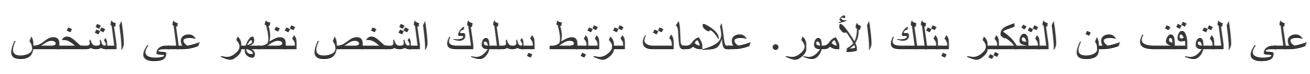
الذي يعاني من ضغوط نفسية مجموعة من السلوكيات، نذكر منها ما يلي:آس] إظهار الاضطراب الدائم. قضم الأظافر. البكاء أو الصراخ. السخرية من الناس وزجرهم. حلك الجلد.

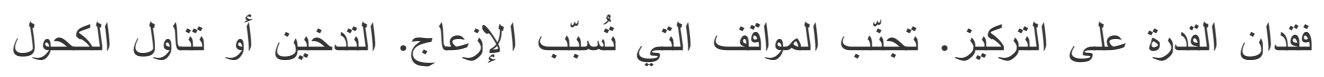
بشكلٍ مبالغ فيه. مواجهة صعوبة في اتخاذ القرارات. فقدان القدرة على الثبات في المكان 
ذاته. اختلاف السلوك بما بتعلق بتتاول الطعام، فالبعض قد بتتاول كميات أكبر من تلاك

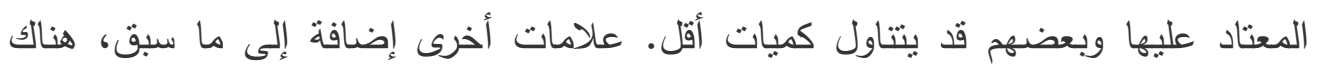
علامات أخرى تتمثل بانعكاس تأثير الضغوط النفسية في صحة الثخص وسيات وسلامة جسده، ويظهر ذلك على النحو الآتي:[؟] الصداع. آلام الصدر. الثند العضلي. التهاب العيون. ارتفاع ضغط الدم. عدم وضوح الروئة. التنفس الضحل أو فرط التنفس (بالإنجليزية : الشعور بالتعب طول الوقت. المعاناة من نوبات الهلع والخوف. (Hyperventilation).

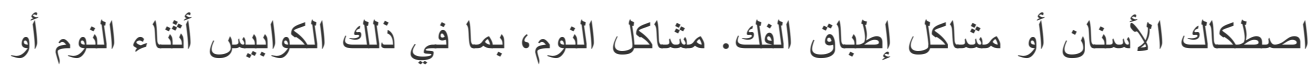

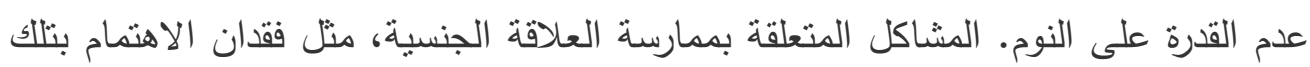
العلاقة أو عدم القدرة على الاستمتاع بها. الإمساك أو الإسهال. الثعور بالغثيان أو بالدوار.

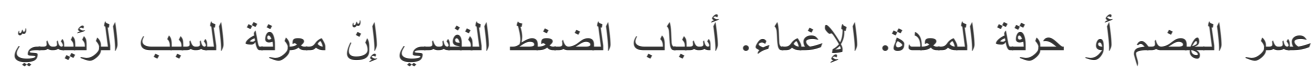

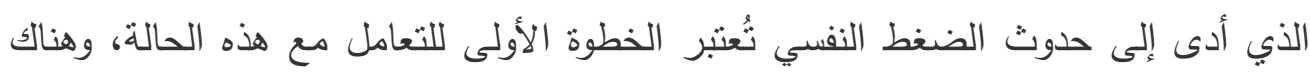

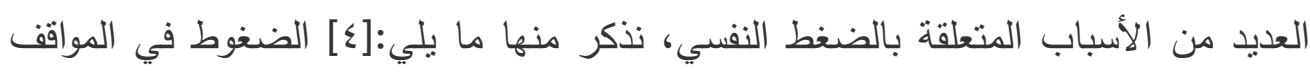

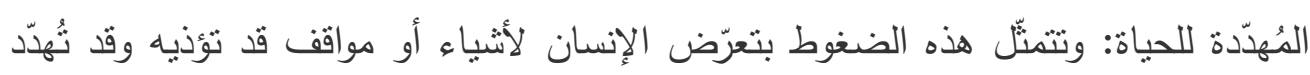

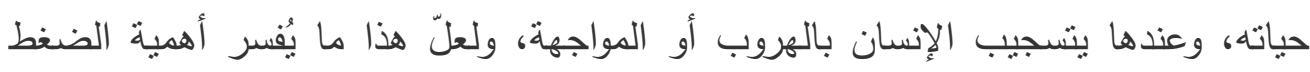

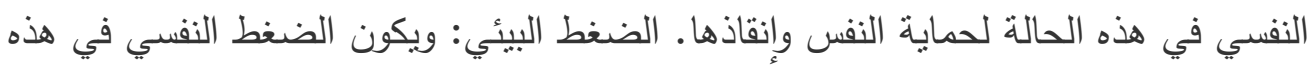

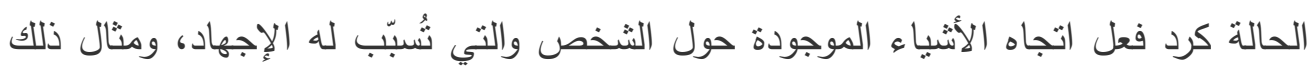

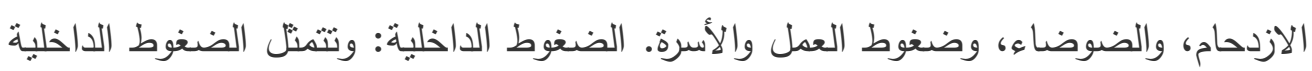
بقلق الإنسان وتوتزه اتجاه الأشباء التي لا تستحق التوتر والقلق، أو معاناته من استمرار

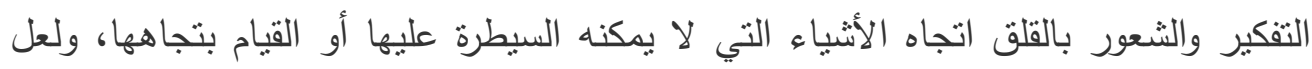

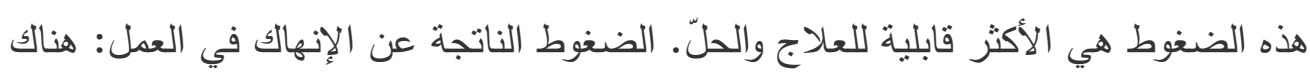

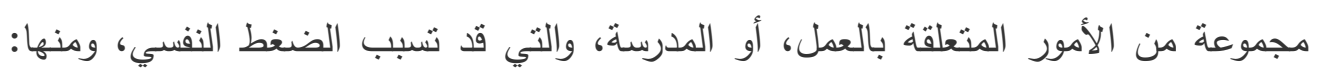

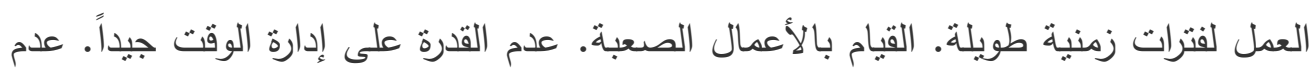

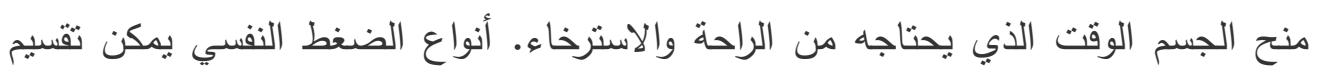

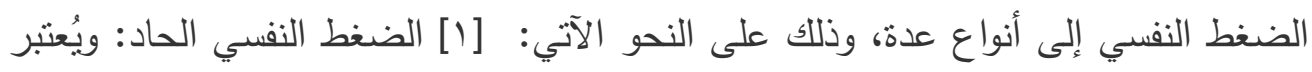
هذا النوع أكثر أنواع الضغط النفسيّ شيوعاً، ويستمر لفترات قصيرة من الزمن، وبرتبط الفيط حدوثه

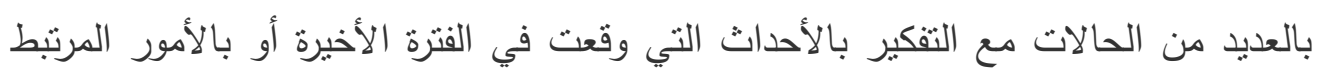

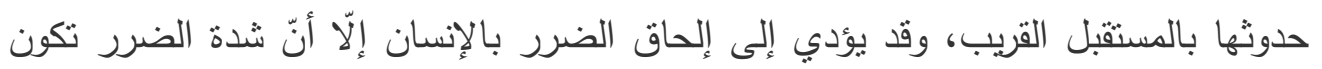


أخف من نلك التي يسببها الضغط النفسي المزمن، وإذا استمر هذا الضغط لفترات طويلة من الزمن فإنّه قد يتحول من حاد إلى مزمن، ويصاحب حدوث الضغط النفسي الحاد الثعور بالتوتر، والضيق، والصداع، إضافة إلى اضطرابات المعدة وذللك لفترات قصيرة. الضغط إلى النفسي الحاد النوبي: وفي هذه الحالة يُعاني الأشخاص من الإجهاد الحاد بشكلٍ متكرر، إقلى ويرتبط هذا النوع من الضغوط بالأشخاص الذين يشعرون بالقلق أكثر من اللازم أو أولئك بـاني

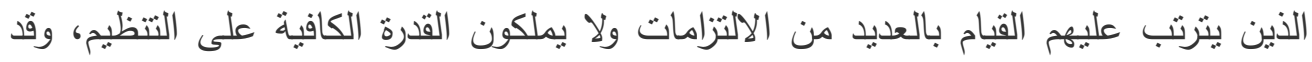

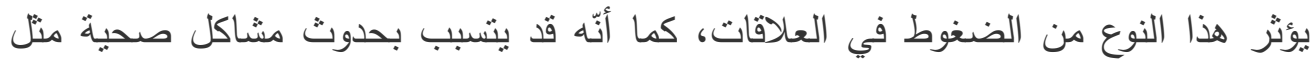
ارتفاع ضغط الدم وأمراض القلب. الضغط النفسي المزمن: ويُعتبر هذا النوع هو الأكثر ضرراً

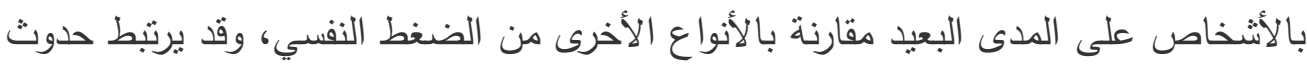

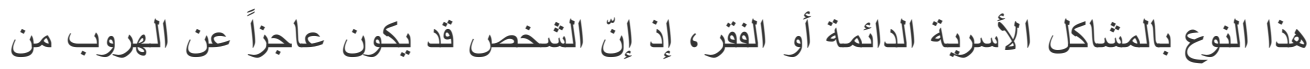

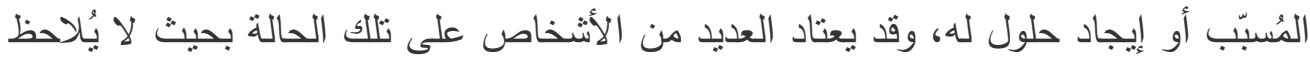

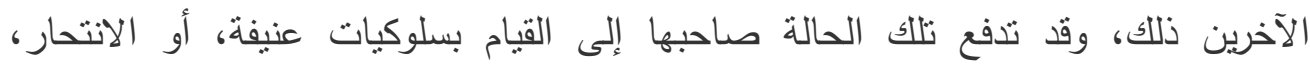

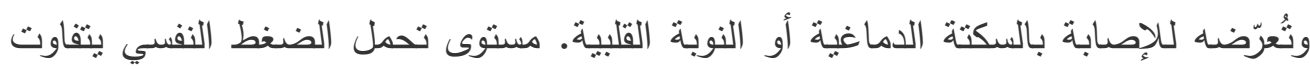
الأفراد في قدراتهم على تحمل الضغط النفسيّ، وهناك العديد من العوامل التي تؤثر في بـني مستوى تحمل الثخص للضغوط النفسية، نذكر منها ما يلي:[0] الدعم المعنويّي: إذ إنّ وجود أفراد العائلة والأصدقاء الداعمين حول الثخص له دور في التصدي للضغوط ومواجنها، في حين أنّ الثخص الذي يشعر بالوحدة نزداد احتمالية تعرّضه للضغط النفسيّ. القدرة على دوري التعامل مع العواطف: إذ إنّ الثخص الذي يمنلك القدرة على تهدئة نفسه عند شعوره بالغضب، أو الحزن، أو القلق يكون أقل عرضة للضغط النفسي. موقف الثخص وتوقعاته:

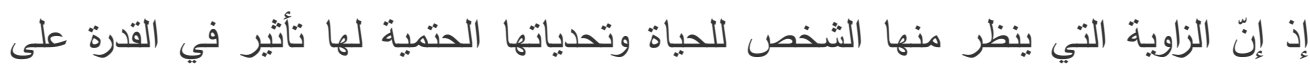
التعامل مع الضغط، فالثخص المتفائل الذي يتمتع بحس الفكاهة والذي يقبل التحديات سيكون أقل عرضة لخطر الضغوط. المعرفة والتحضيرات: إذ إنّ معرفة الثخص وإدراكه

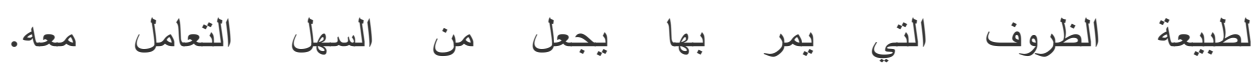

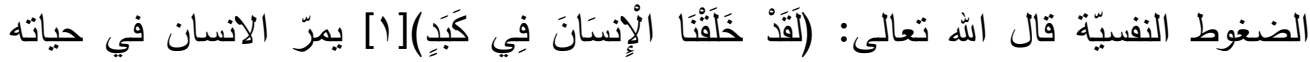
بالكثير من الضغوط والأزمات والثدائد والمشقّات التي من شأنها أن تؤثر سلباً في حياته فئه

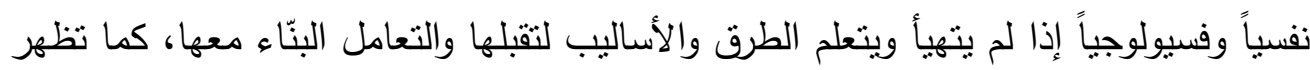
أهمية التسليم والقناعة بأنه لبس هناك مناص ومفرٌ من مرور الإنسان في منل هذه الأزمات، 
وأنه من غير المككن منعها جميعها من الحصول. أما استجابات الأفراد لهذه الضغوط فإنها

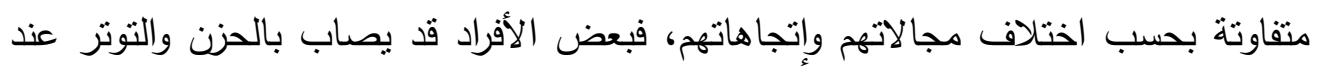

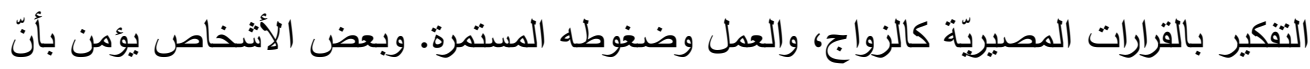
تعرّض الإنسان للضغوط من فترة إلى أخرى يجعله أكثر قدرة وكفاءة على القيام بالمهام وإنجازها وأكثر جرأة على خوض التحديات والنجاح فيها، وبالتالي حصول الفرد على الثعور

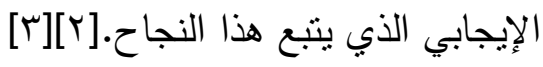
تعريف الضغوط النفسية اختلفت تعريفات مصطلح الضغط النفسي باختلاف الاتجاه

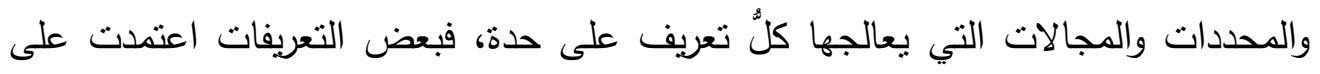
التركيز على عامل المثير الخارجي، وبعضها الآخر اعتمدت على معالجة الاستجابات للمثيرات المختلفة، وهناك تعريفات قامت أيضاً على دراسة عامل المثير والاستجابة معاً. عرّف معجم التحليل النفسي مصطلح الضغط النفسي على أنّه جميع العوامل الخارجيّة التي دُبي

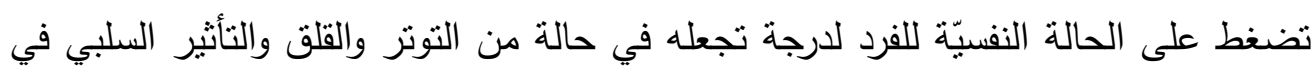
قدرنه على تحقيق التكامل والتوازن في شخصيته، بالإضافة إلى فقدان الاتزان الانفعالي

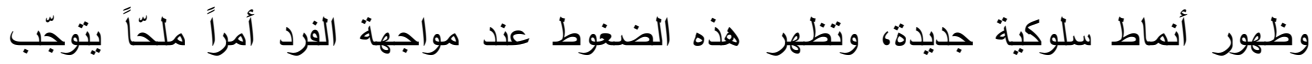

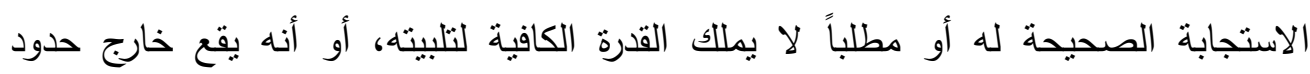
استطاعته، كما عرّف الكثير من العلماء. مصطلح الضغوط النفسية كالآتي:[؟] عرّفها العالم لازاروس: بأنها مجموعة من

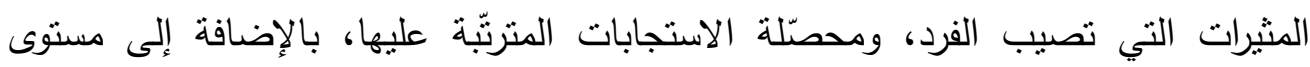

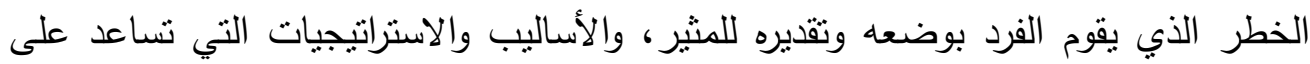

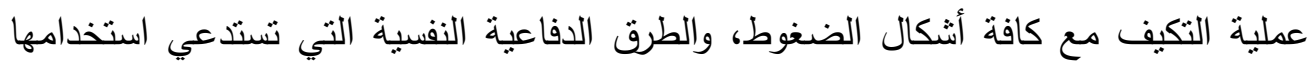
في الظروف المختلفة. تعريف العالم ولتر جملش: هي التوقعات والأفكار المُسبقة التي تتكوّن

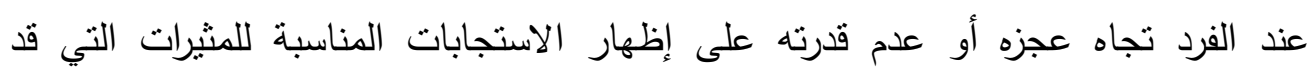

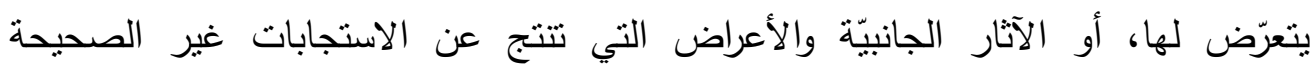
والخاطئة. تعريف العالم جيمس كويك وجوناثان كويك: الضغوط النفيّة هي الاستجابات التي تثمل حالة اللاشعور التي يمرّ بها الفرد، حيث تتطلب منه استنزاف واستتفار كافة أثنكال

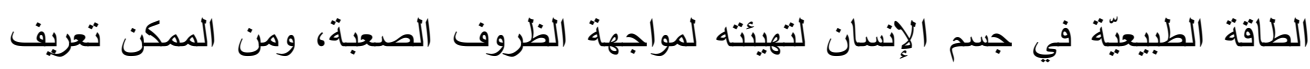

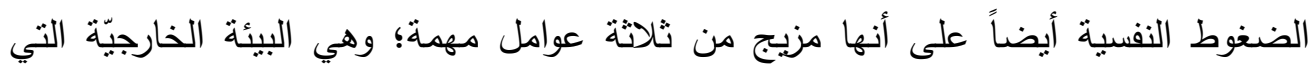


يعبش فيها الفرد، والمشاعر والأحاسيس السلبيّة التي تسبطر على الفرد، بالإضافة إلى

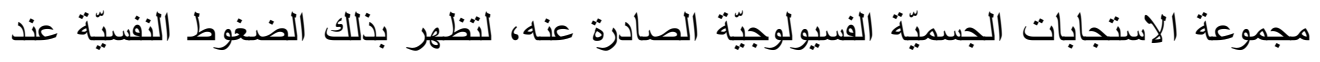
تفاعل هذه العوامل مع بعضها بطرق خاصة، لنُتج بدورها حالات القلق والاكتئاب والتوتر التي تسيطر على ذات الفرد ونفسيّته. مصادر الضغوط النفسية هناك الكثير من التصنيفات لمصادر الضغوط النفسيّة، فمن الممكن تقسيمها على أنها داخليّة ذاتيّة المنشأ أو بيئيّة

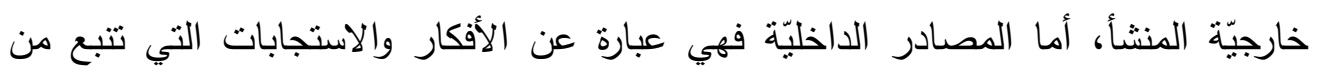

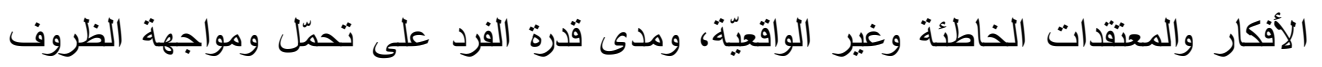

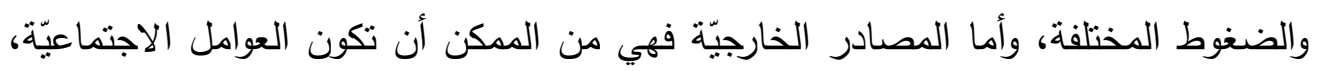
والصراع بين القيم والعادات والمعتقدات وبين الواقع، بالإضافة إلى الأحداث والتغيّرات

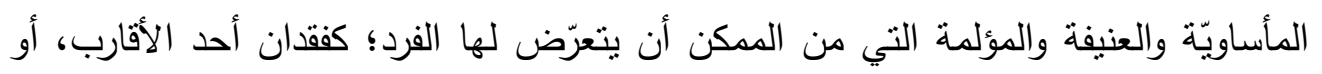

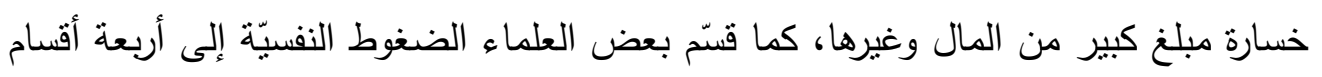
[0]

العوامل البيئيّة: كالتقلّبات المناخية، وحالات التلوّتث والتغيرات المفاجئة في حالة الطقس. العوامل الفسيولوجيّة الجسمية: وهي العوامل التي تخصّ البنية الجسمية للفرد مثل: المرور

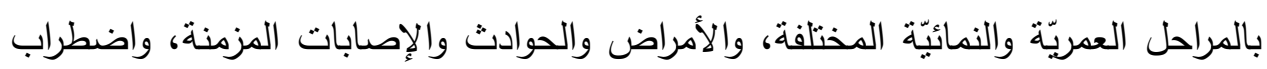

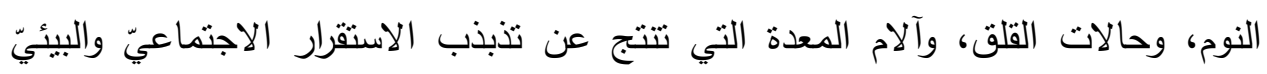
والخوف من حدوث التغيرات الطارئة. العوامل الاجتماعية: كالمواعيد والمقابلات المصيريّة والمهنيّة، والتعرض للمشكلات المالية، والخوف والتوتر عند الإقدام على إلقاء محاضرة أو أولئه

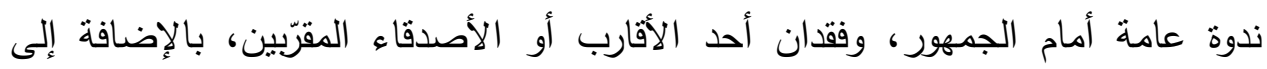

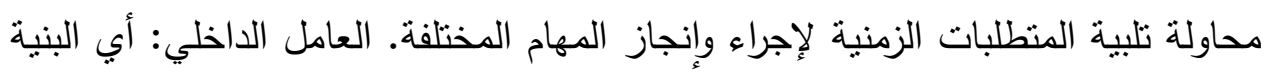

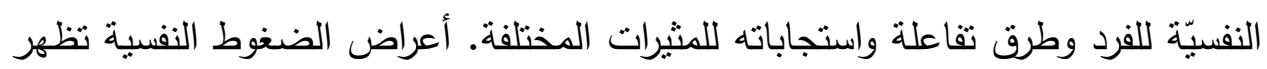

على الفرد الذي يقع تحت وطأة الضغوط النفسيّة الكثير من الأعراض، وهي كالآتي:[0]

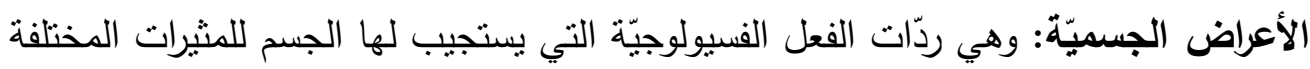

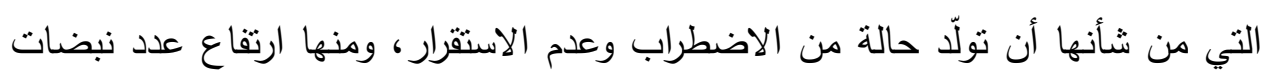

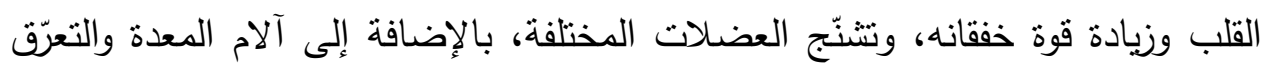

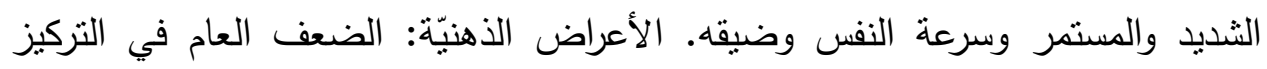

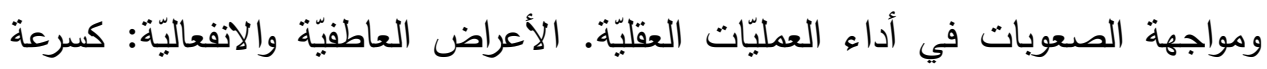


الاستتارة والغضب والانفعال والقلق والتوتر، وقد نظهر بعض الانفعالات الباردة نسبيًا التي

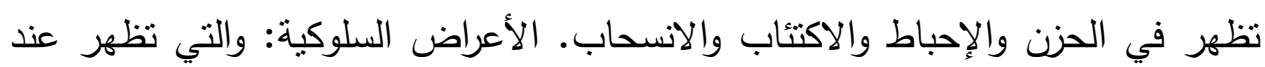

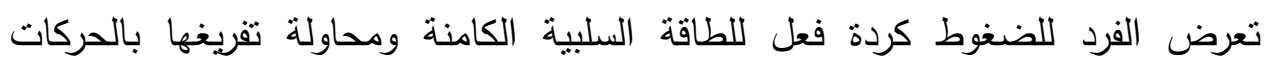

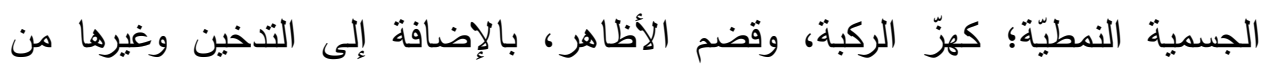

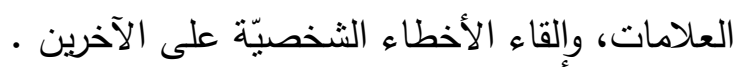

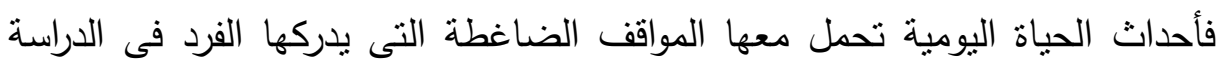

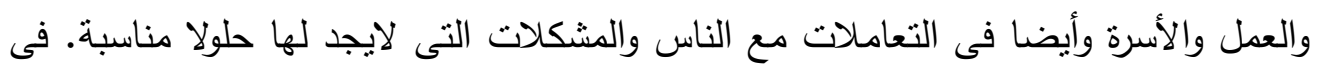

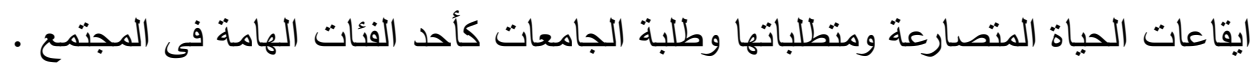

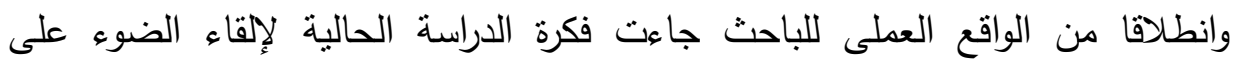
مسنوى الأثار النفسية لالتحاق الطالبات المنزوجات بالدراسة : هي الإنمات الإنعكاسات النفسية الإيجابية والسلبية التي تطرأ على المرأة وأسرتها من خلال زواجها ودراستها.

\section{مشكلة الاراسة:}

نظراً لاهتمام الباحث بالمرأه عمومأ والمتزوجة على وجه الخصوص وما تواجهه من تحديات يومية قد تؤثر على نفسيتها بالاضافة الى اهتمام وملاحظات. وتعتبر الآثار النفسية مشكلة تسيطر على الجميع وليس فقط على فئه المتزوجات وحسب، لكنها تنزايد في حدتها مع هذه الفئة كونها تجمع ما بين الزواج والدراسة، وتمر طالبات الجامعات بمرحلة مهمة

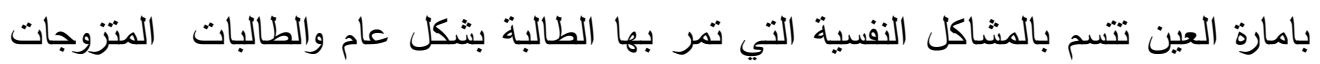

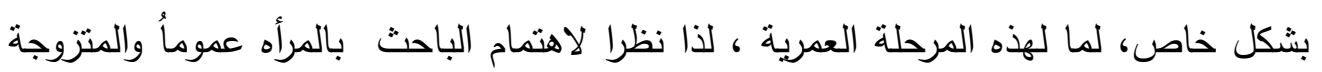

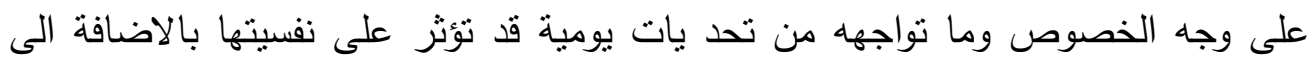

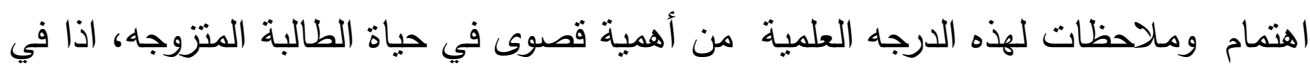

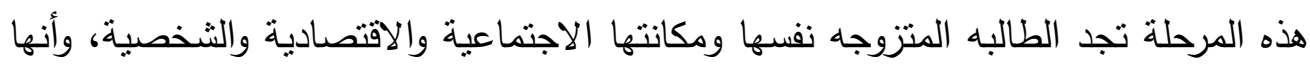

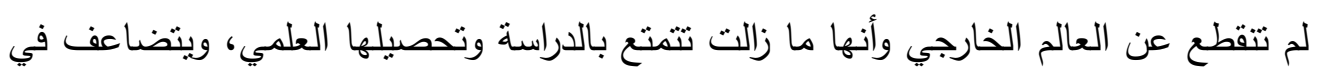

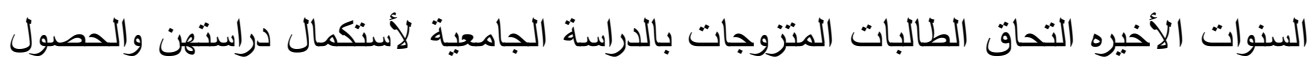

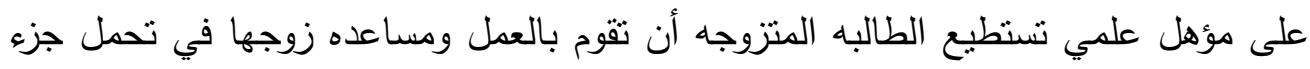

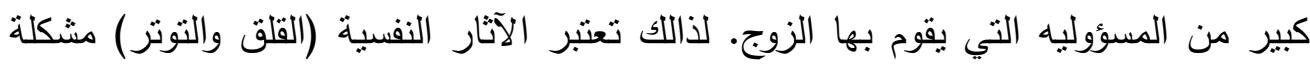
تسيطر على الجميع وليس فقط على فئه المنزوجات وحسب، لكنها تتزايد في حدتها لهذه الفئه كونها تجمع ما بين الزواج والدراسة. 


\section{أسئلة الدراسة:}

1- ما درجة الآثار النفسية لالتحاق الطالبات المنزوجات بالدراسة في امارة العين على حياة

$$
\text { أسرهن من وجهه نظرهن؟ }
$$

r-هل يوجد فرق ذو دلاله إحصائية لالتحاق الطالبات المتزوجات بالدراسة في امارة العين

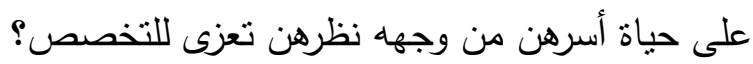

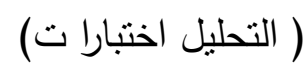

r- هل يوجد فرق ذو دلاله إحصائية لالتحاق الطالبات المنزوجات بالدراسة في فى امارت العين ابوظبى على حياة أسرهن من وجهه نظرهن للمستوى الدراسي؟(اختبار تحليل التباين الأحادي)

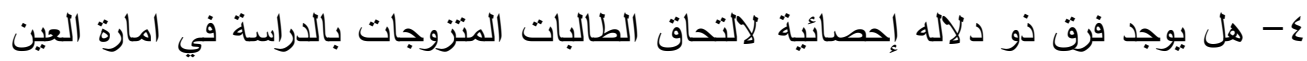

على حياة أسرهن من وجهه نظرهن تعزى للجنسية؟ دوف دله

الاهمية:

أن التعليم هو النافذه التي تطل منه المرأة على حضارة الأمم، وهو وسيلتتا لمواكبة المسيرة التقدم والتطور واستمرار النهوض لمجتمعنا". وذلك للمقولة التي تقول: اذا علمت رجلأ فقد علمت فردأ، واذا علمت امرأة فقد علمت أسرة باكملها".

\section{فروض الدراسة}

ا.توجد علاقة ذات دلالة احصائية بين الاثار النفسية (القلق والتوتز) لالتحاق الطالبات المتزوجات بالدراسة في امارة العين على حياة اسرهن من وجهة نظرهن

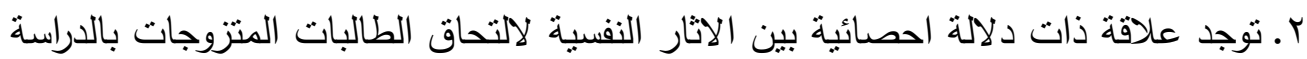
في امارة العين لتربية الطفل . r- توجد علاقة ذات دلالة احصائية بين الاثار النفسية (القلق والتوتر) لالتحاق الطالبات المتزوجات بالدراسة في امارة العين وبين العلاقة الاسرية.

حدود الاراسة:

تتحدد هذه الدراسة بالمنطقه التي تعمل بها الدراسه وهي في امارة العين ، وعلى طالبات البكالوريوس المتزوجات والملتحقات بدراسة تخصص نربية الطفل والتربية الخاصه. 


\section{مصطلحات الدراسة:}

- الأثار النفسية لالتحاق الطالبات المتزوجات بالدراسة: هي الانعكاسات النفسية الإيجابية

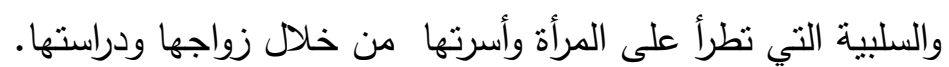

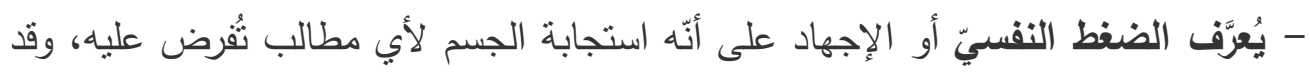
تكون هذه المطالب متعلقة بالوظيفة، أو الوضع المالي، أو العلاقات، أو الجوع، أو أولئ

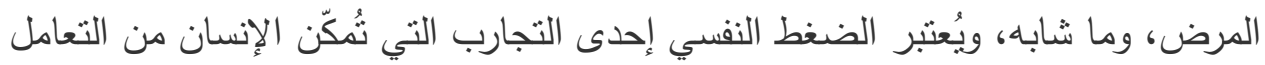
مع المواقف الصعبة، وقد يكون مُحفزاً لتخطي العقبات والبقاء على قيد الحياة، ويكون أداء

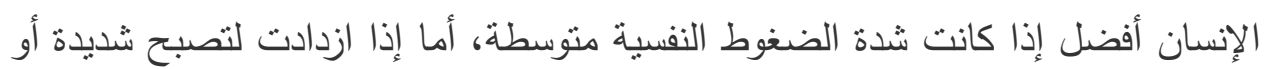

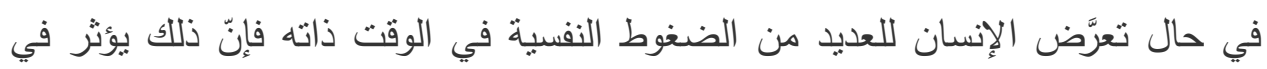
أدائه بشكلٍ سلبي وقد يكون ذللك سبياً في التأثنر في صحة الإنسان العقلية والجسدية - التوتر :- انّ مشاعر القلق والتوتر مشاعر تصيب أغلب الناس من وقتٍ لآخر ، وعادة يكون التوثّر نتيجة أمورٍ يفكّر فيها الإنسان وأمور تنقل عليه نفسيّاً أو جسيَّاً، وواجباتٍ

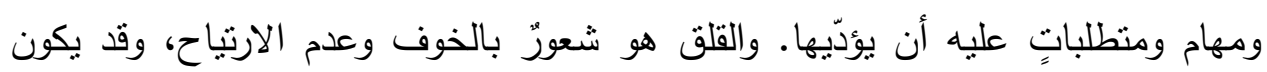

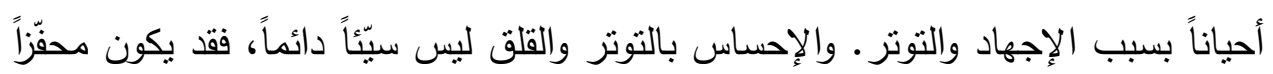

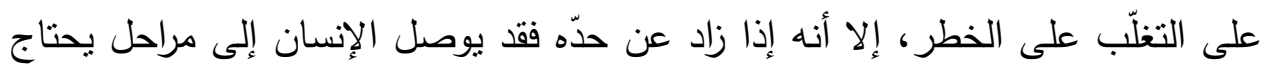

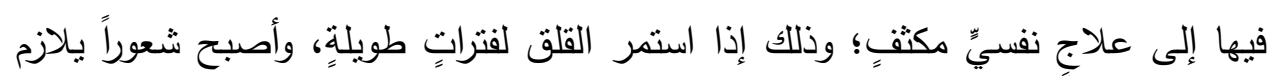

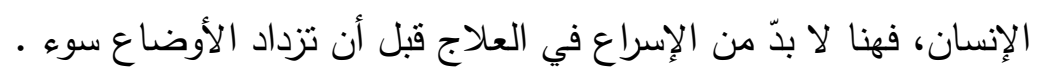

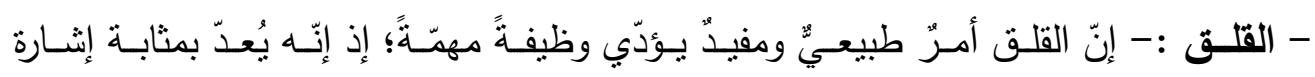

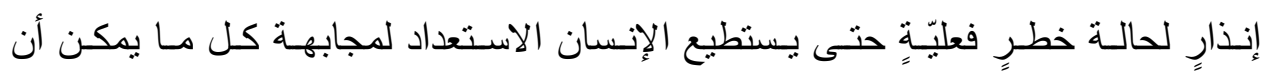

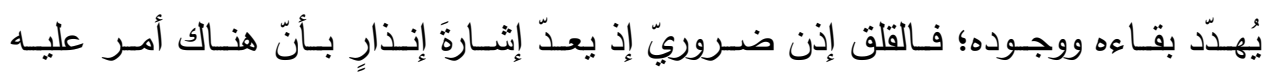

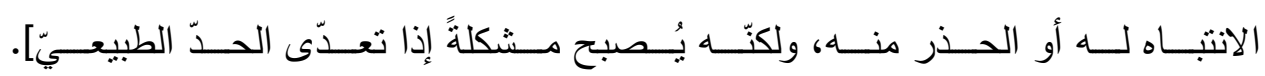

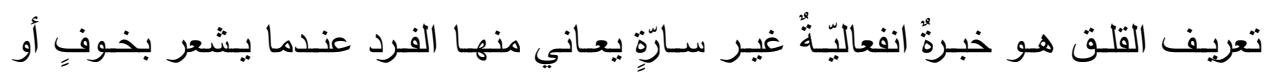

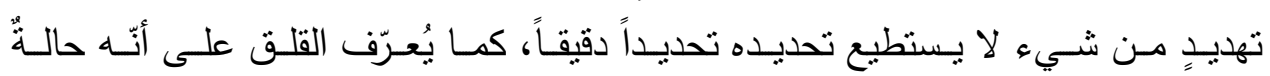

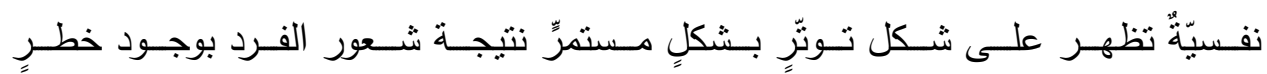

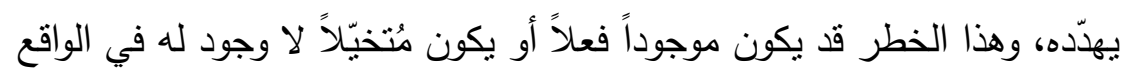




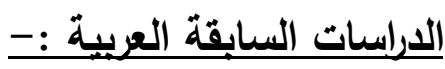

اولا : الاراسات العربية . العاتية

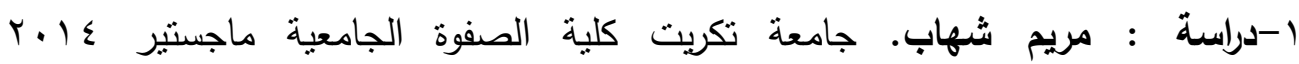

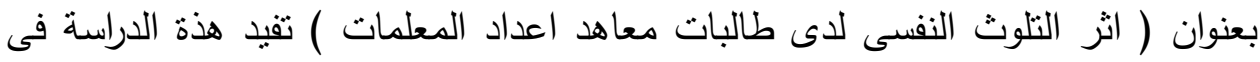
اعتمدة الدراسة على كيفية اعداد مقياس للكثف عن مستوى التلوث النفسى لدى الطالبات وايضا البيانات وكيف عالجتها احصائيا باستعمال كاى ،معامل ارتباط بيرسون ـ الاختبار الثانى لعينتين مستقلتين .اختبار ولكوكسونهوتوصلها الى وجود فروق فردية دلالة احصائية لاى المجموعة التجريبية فى القبلى والبعدى فى التلوث النفسى ولصالح

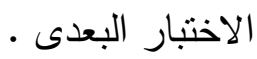

ץ-دراسة :- جمال شفيق احمد محمد عامر جامعة عين شمس دكتورة 911 ا: بعنوان ( اثر استخدام البرنامج ارشادى التوتر النفسى لاى طالبات المرحلة الثانوية ). نجد

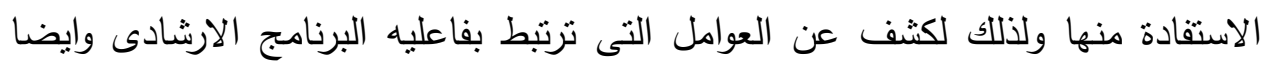
العوامل التى يمكن ان تؤدى الى عدم فاعليته وقد استخدم الباحث الاساليب الاحصائيه الاتيه : أ) الربيع الاعلى لتحديد افراد عينتى الدراسه (التجريبيه والضابطه (اللاتى يعانين

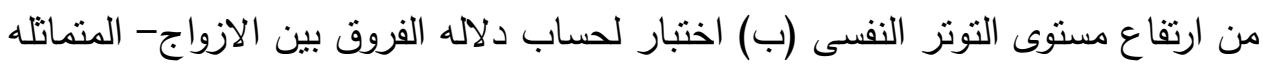

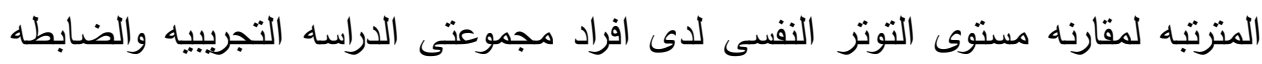
بعد استخدام البرنامج بمستواه قبل تطبيقه .

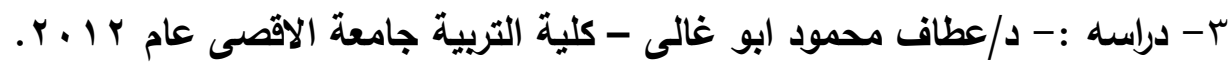
بعنوان(فاعلية الذات وعلاقتها بضغوط الحياة لدى الطالبات المتزوجات فى جامعه الاقصىى). تهدف هذة الدراسة الى كثف العلاقة بين فاعلية الذات وضغوت الحياة لدى الطالبات المتزوجات فى جامعة الاقصى والتعرف على مستوى كل من فاعلية الذات وضفوط الحياة لايهن وتفيد هذة الدراسة الدراسة الحالية فى اظهار وجود فروق فردية فى ضنغوط الافي الحياة

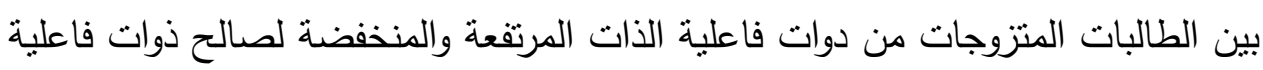
الذات المنخفضة. ع- دراسة :- هيا بنت ابراهيم بن عبد العزيز - جامعة ام القرى بعنوان( الرضا الزوجى

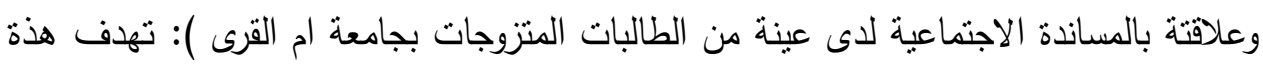

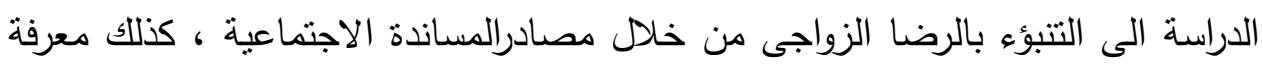


الفروق بين افراد العينة فى درجات الرضا الزوجى باختلاف بعض المتغيرات والتى شملت

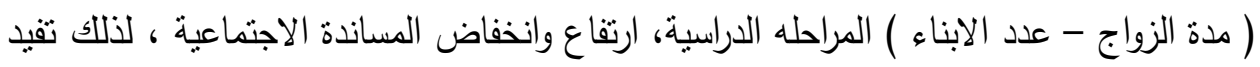
الدراسة الحالية فى وجود علاقة ارتباطية موجبة وداله احصائيا بين الرضا الزوجى لرواه والمساندة الاقتصادية لدى افراد العينه . ه- دراسة :- كرديك 1999 ( دراسة طولة لاضا الوالدى والرضا الزوجى للاباء والامهات الذين لديهم اطفال صغار ) انها لم تجد قيم ذات دلاله احصائية بين عمر الاطفال وعددهم وكل من الرضا الزوجى وتقيد الدراسة الحالية فى ان نتائجها تبين ان الرضا

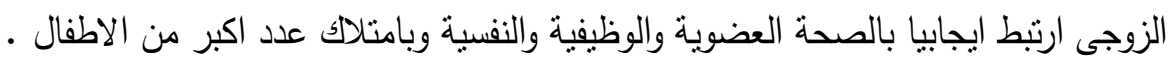

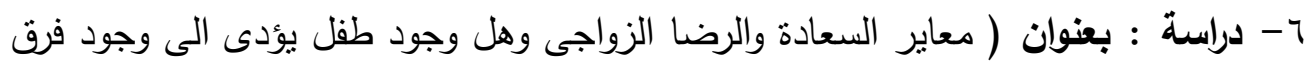

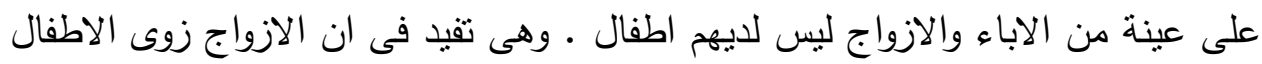

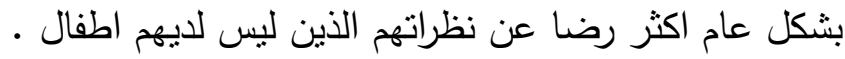
V- دراسة : الجود وإخرون 1997 والتى تبدأ بالاثشارة الى وجود مساندة من الناحية التجريبية والنظرية للصداقة ولعملية المساندة الاجتماعية بين الزوجات والازواج بيبين فائدتهما على الرضا الزوجى وقد اثارت الدراسة الحالية الى الانعكاسات النفسية الإيجابية

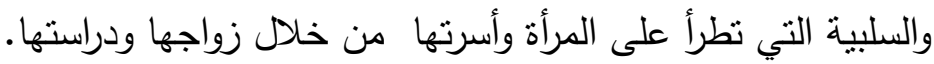

\section{منهرج الدراسة: -}

أعتمد في هذه الدراسه المنهج الوصفي باستخدام الأستبانه لملائمته لأهداف هذه الدراسة

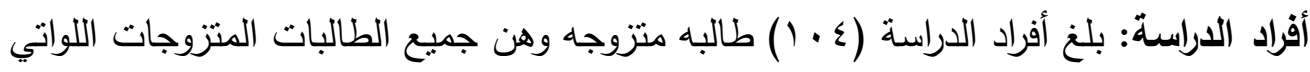
يدرسن في قسمي بكالوريوس تربية الطفل، والتربية الخاصة بامارت العين ابوظبى.

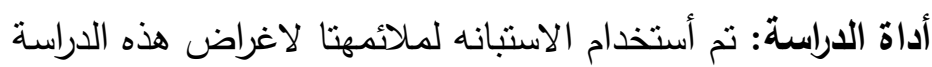
متغيرات الدراسة : التخصص، المستوى الدراسي، الجنسية.

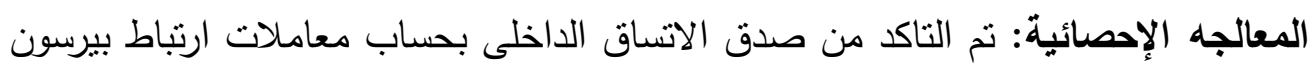
بين درجات كل مجال من المجالات والدرجة الكلية وذلك من خلال نطبيق المقياس على الى

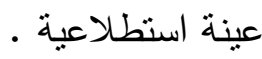


جدول رقم (1) يوضح توزيع أفراد عينة الدراسة حسب متغير تربية طفل

\begin{tabular}{|c|c|c|}
\hline النسبة المئوية & التكرار & الجنس \\
\hline$r \leq . \leq q$ & $r \varepsilon$ & تربية طفل \\
\hline$v 0.01$ & $V \varepsilon$ & تربية خاصة \\
\hline $1 \ldots$ & $9 \wedge$ & الدجموع \\
\hline
\end{tabular}

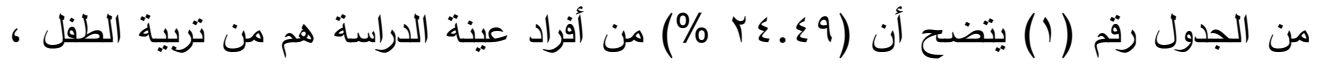

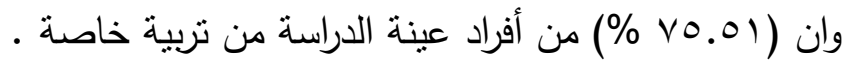

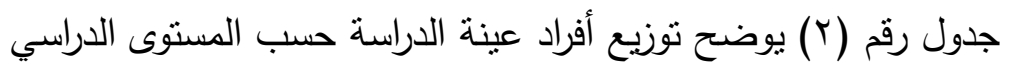

\begin{tabular}{|c|c|c|}
\hline النسبة المئوية & التكرار & الدخل \\
\hline rq.1V & rA & سنة أولى \\
\hline$r 9.01$ & rᄉ & سنة ثانية \\
\hline $10.7 \pi$ & 10 & سنة ثالثة \\
\hline $10.7 \pi$ & 10 & سنة رابعة \\
\hline$\% 1 \ldots$ & 91 & المجموع \\
\hline
\end{tabular}

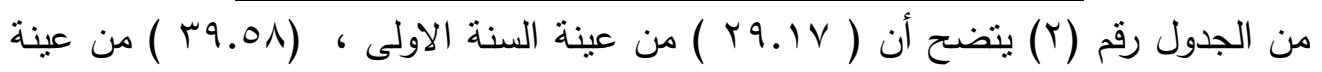

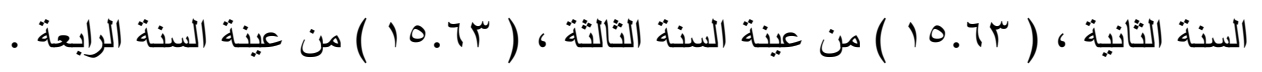
جدول رقم (ץ) يوضح توزيع أفراد عينة الدراسة حسب منغير الجنسية

\begin{tabular}{|c|c|c|}
\hline النسبة المئوية & التكرار & الجنس \\
\hline$r \leqslant . \leqslant 9$ & $r \varepsilon$ & غير الامارتيات \\
\hline$v 0.01$ & $V \varepsilon$ & الامارتيه \\
\hline $1 \cdots$ & 91 & المجموع \\
\hline
\end{tabular}

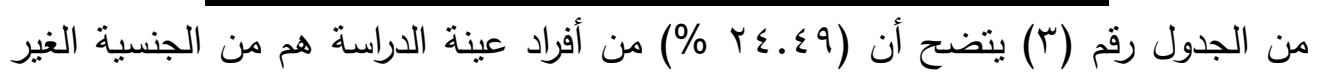

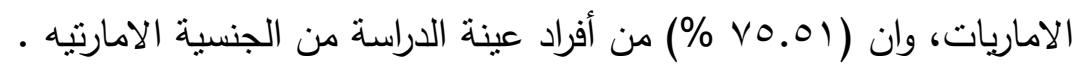
ثبات أداة الدراسة :

لاختبار الثبات، قام الباحث باستخدام اختبار كرونباخ ألفا (Cronbach's Alpha)

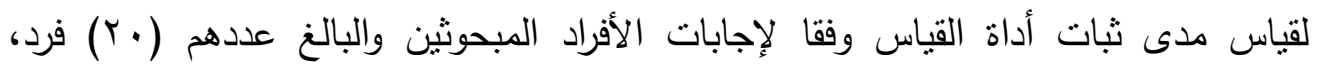

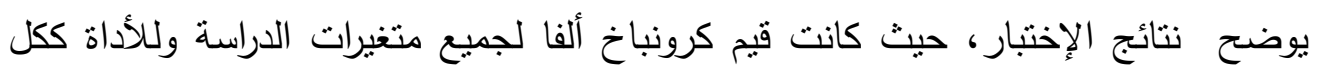
مقبولة في البحوث والدراسات الإنسانية. 
تم استخدام اختبار (كرونباخ ألفا) لقياس مدى ثبات أداة القياس حيث بلغت قيمة ألفا

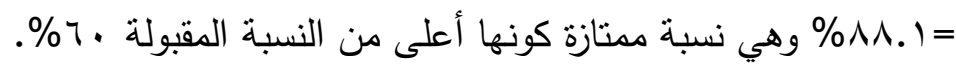
اختبار الفرضيات

الفرضية الرئيسئة:

Ho

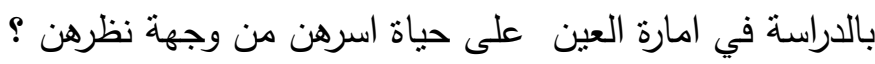

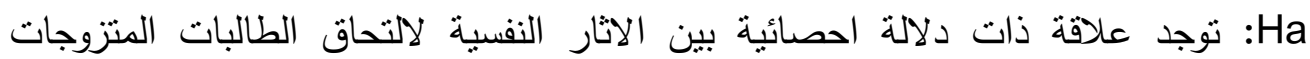

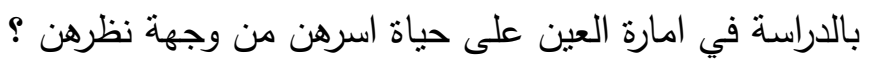
جدول رقم (1 ) نتائج اختبار الفرضية

\begin{tabular}{|c|c|c|c|}
\hline نتيجة الفرضية العدمية & SIG $t$ & الجدولية t & المحسوبة t \\
\hline رفض رف & $\cdots \cdots$ & 1.97 & 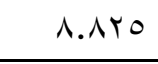 \\
\hline
\end{tabular}

فقد نم استخدام اختبار الانحدار البسيط ونجد من مطالعتتا لنتائج الحاسوب في الجدول

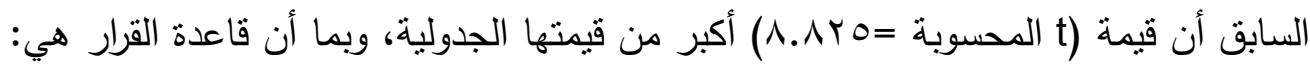
ثقبل الفرضية العدمية (Ho) إذا كانت القيمة المحسوبة أكبر من القيمة الجدولية، وبالتالي

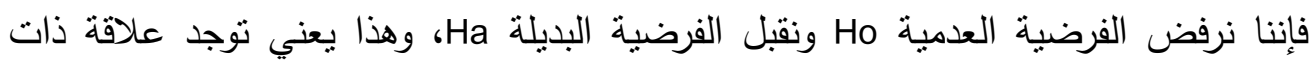
دلالة احصائية بين الاثار النفسية لالتحاق الطالبات المتزوجات بالدراسة في امارة العين على الثلى

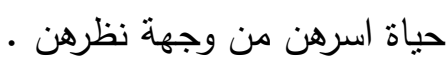

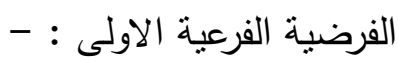
Ho

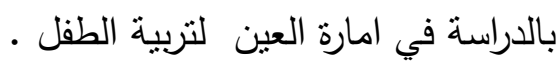
Ha

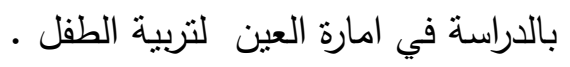
جدول رقم (r ) نتائج اختبار الفرضية

\begin{tabular}{|c|c|c|c|}
\hline نتيجة فرضية العدم & SIG $\mathrm{t}$ & t الجدولية t & t الدحسوبة t \\
\hline رفض & $\ldots \leqslant V$ & r... & r.. ro \\
\hline
\end{tabular}

فقد نم استخدام الانحدار البسيط ونجد من مطالعتنا لنتائج الحاسوب في الجدول

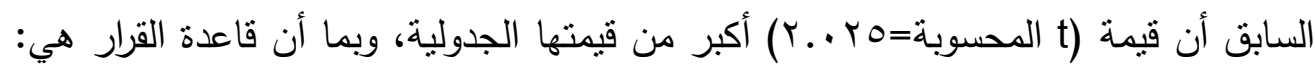


تقبل الفرضية العدمية (Ho) إذا كانت القيمة المحسوبة أقل من القيمة الجدولية، وترفض الفرضية العدمية (Ho) إذا كانت القيمة المحسوبة أكبر من القيمة الجدولية، بالتالي فإننا

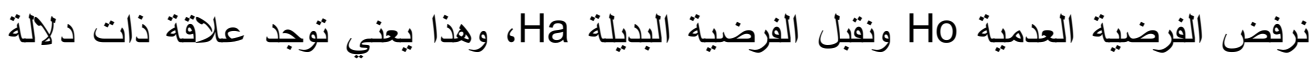
احصائية بين الاثار النفسية لالتحاق الطالبات المتزوجات بالدراسة في امارة العين لتربية الطفل .

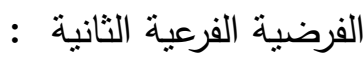
Ho بالاراسة في امارة العين وبين العلاقة الاسرية.

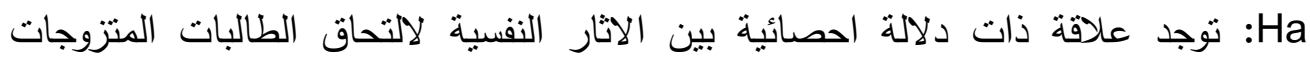
بالدراسة في امارة العين وبين العلاقة الاسرية. جدول رقم (V) نتائج اختبار الفرضية

\begin{tabular}{|c|c|c|c|}
\hline نتيجة فرضية العدم & $\overline{\text { SIG t }}$ & t الجدولية & | المحسوبة t \\
\hline رفض & ...r & r... & Y.Y.T \\
\hline
\end{tabular}

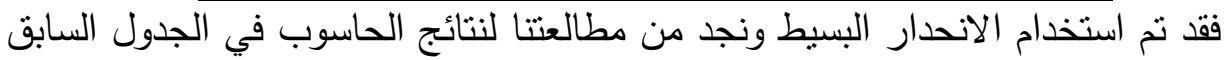

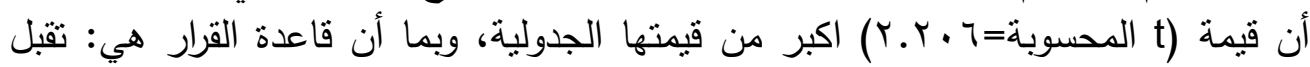

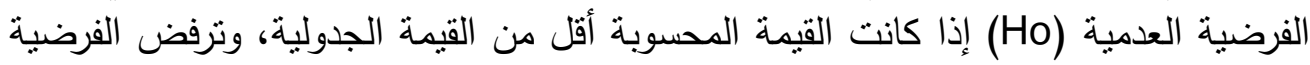

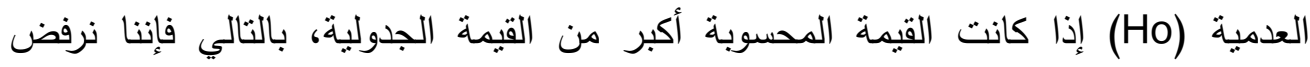

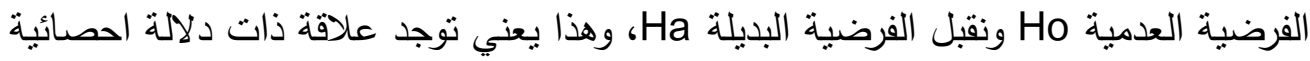
بين الاثار النفسية لالتحاق الطالبات المتزوجات بالدراسة في امارة العين وبين العلاقة الاسرية. التنتائج ا. توجد علاقة ذات دلالة احصائية بين الاثار النفسية لالتحاق الطالبات المتزوجات بالدراسة

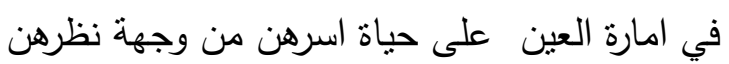
r. توجد علاقة ذات دلالة احصائية بين الاثار النفسية لالتحاق الطالبات المات المتزوجات بالدان الدراسة

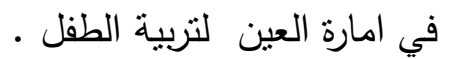
r. توجد علاقة ذات دلالة احصائية بين الاثار النفسية لالتحاق الطالبات المتزوجات بالدراسة في امارة العين وبين العلاقة الاسرية. 


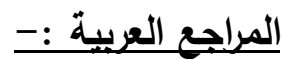

1- ابراهيم زكريا (7919 (). الزواج والاستقرار النفسي ـ طب ـ القاهرة ، مكتبة مصر .

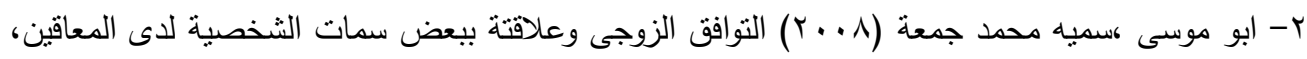

رسالة ماجستير . كلية التربية الاسلامية .غزة .

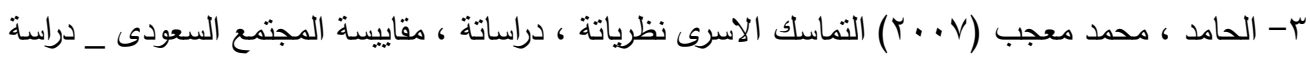

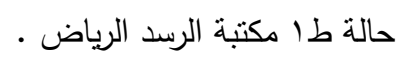

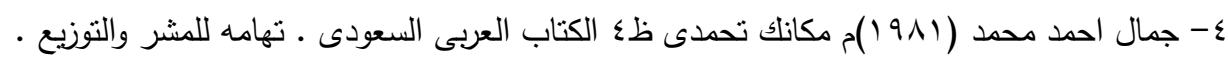

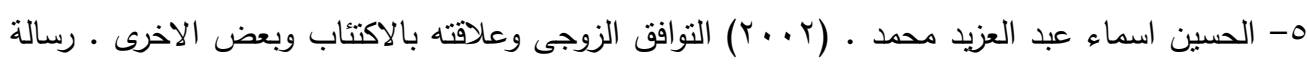

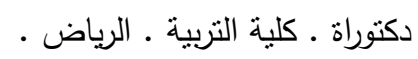

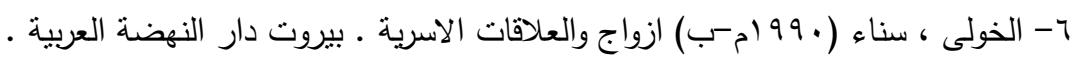

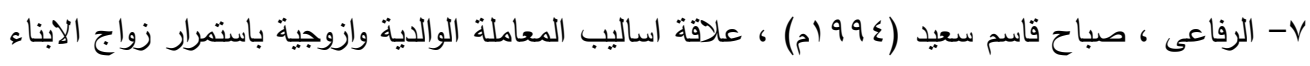

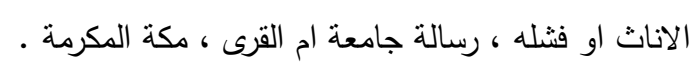

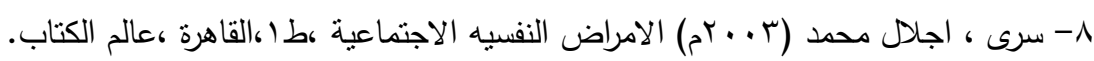

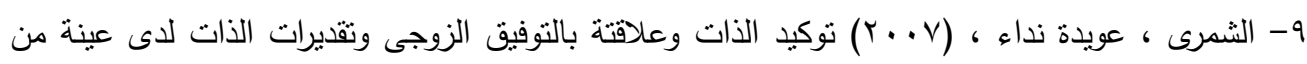

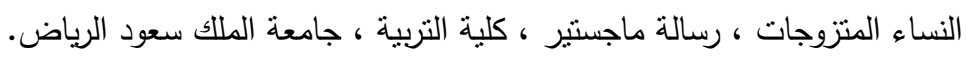

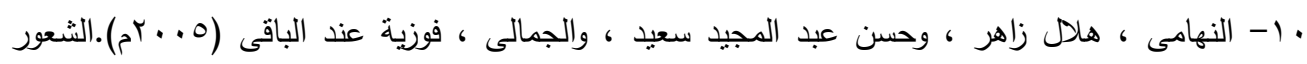

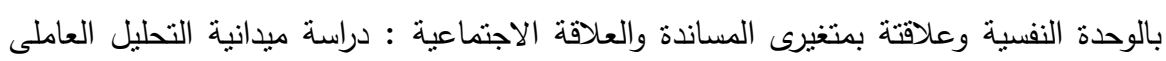

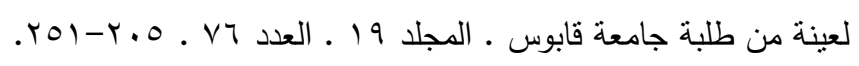

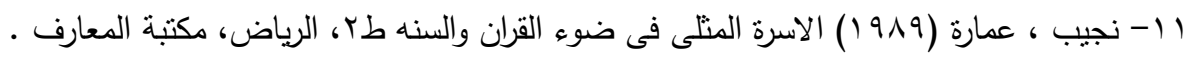

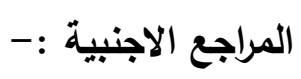

12-Acitelli.LindaK,\&Toni C.Antonucci.(1994).Gender differences in the link between marital support and satisfaction in older couples' ournal of personality and social psy chology, $67 \mathrm{n} 4 ; 688(11)$.

13- Orathinkal,j.\&.alfons.V.(2007).demographic affect marital satisfaction - Journal of sex and martial therapy .33;73-85. 